\title{
Accelerated aging predicts the emergence of rice seedlings in the field
}

\section{Envelhecimento acelerado prediz a emergência de plântulas de arroz em campo}

\author{
Jaquelini Garcia; Cileide Maria Medeiros Coelho*
}

\section{Highlights}

Accelerated aging test show high correlation with field emergence.

The emergence index and dry weight also show high correlation with field emergence.

Accelerated aging is the best option due practicality and time required to execute.

\begin{abstract}
Selecting the most appropriate vigor test for rice to predict seedling emergence remains a challenge. This is mainly attributed to the diversity of available tests that evaluate vigor; however, there is a critical need for tests that can show a high correlation with field emergence. Thus, this study aimed to determine which vigor tests are the most efficient in predicting the emergence of rice seedlings, to facilitate correct selection for quality control analyses and pre-sowing for rice seed commercialization. Across two growing seasons, 2016/17 and 2017/18, different seed lots of 'SCS122 Miura' rice were subjected to vigor evaluations including germination test, electrical conductivity, cold test, low temperature germination, accelerated aging, root and shoot length, seedling dry weight, emergence speed, and emergence speed index, and greenhouse and field emergence tests. A completely randomized design with four replicates was used for the experiments. All statistical analyses were performed using R software. The germination rate for 'SCS122 Miura' seed lots in both growing seasons was greater than $80 \%$. In both growing seasons, unlike the similar results obtained for field emergence, in the laboratory tests, differences were observed between these same seed lots. Electrical conductivity and emergence speed showed a negative correlation with greenhouse and field emergence. The vigor tests for accelerated aging, emergence speed, and dry weight are more efficient in predicting the emergence of rice seedlings. Among the tested methods, accelerated aging $\left(41^{\circ} \mathrm{C}\right.$ for $120 \mathrm{~h}$ ) is one of the most efficient for predicting the emergence of rice seedlings and the best option for laboratory analysis of quality control and pre-sowing owing to its practicality and time required for execution.
\end{abstract}

Key words: Oryza sativa. Physiological tests. Vigor.

1 Master in Plant Production, Santa Catarina State University, Center for Agricultural and Veterinary Sciences, UDESC/ CAV, Lages, SC, Brazil. E-mail: jaquelini.garcia@hotmail.com

2 Profa Dra, Department of Agronomy, UDESC/CAV, Lages, SC, Brazil. E-mail: cileide.souza@udesc.br

* Author for correspondence

Received: May 18, 2020 - Approved: Feb. 24, 2021 


\section{Resumo}

A seleção do teste de vigor mais adequado para o arroz para prever a emergência de plântulas permanece um desafio. Isso é atribuído principalmente à diversidade de testes disponíveis que avaliam o vigor; entretanto, há uma necessidade crítica de testes que mostrem uma alta correlação com a emergência a campo. Assim, o presente trabalho teve como objetivo determinar quais testes de vigor são mais eficientes em predizer a emergência de plântulas de arroz, a fim de facilitar a seleção para análises de controle de qualidade e pré-semeadura para comercialização de sementes de arroz. Ao longo de duas safras, 2016/17 e 2017/18, diferentes lotes de sementes de arroz 'SCS122 Miura' foram submetidos a avaliações de vigor, incluindo teste de germinação, condutividade elétrica, teste de frio, germinação a baixa temperatura, envelhecimento acelerado, comprimento de raiz e parte aérea, peso seco de plântula, velocidade de emergência e índice de velocidade de emergência e testes de emergência em casa de vegetação e em campo. $O$ delineamento inteiramente casualizado com quatro repetições foi utilizado para os experimentos. Todas as análises estatísticas foram realizadas com o software R. A taxa de germinação para lotes de sementes 'SCS122 Miura' em ambas as safras foi superior a $80 \%$. Em ambas as safras, diferentes dos resultados semelhantes para a emergência em campo, nos testes de laboratório, foram observadas diferenças entre esses mesmos lotes de sementes. A condutividade elétrica e a velocidade de emergência apresentaram correlação negativa com a emergência em casa de vegetação e no campo. Os testes de vigor pelo envelhecimento acelerado, velocidade de emergência e massa seca são mais eficientes na previsão da emergência de plântulas de arroz. Dentre os métodos testados, o envelhecimento acelerado $\left(41^{\circ} \mathrm{C}\right.$ por $\left.120 \mathrm{~h}\right)$ é um dos mais eficientes para predizer a emergência de plântulas de arroz e a melhor opção para análises laboratoriais de controle de qualidade e pré-semeadura devido à sua praticidade e o tempo requerido para execução.

Palavras-chave: Oryza sativa. Testes fisiológicos. Vigor.

\section{Introduction}

Rice (Oryza sativa L.) is an annual species of the Poaceae family, with a C3 photosynthetic system and is adapted to the aquatic environment (Sociedade Sul-Brasileira de Arroz Irrigado [SOSBAI], 2018). Grown and consumed on all continents, rice is notable for its production and cultivation area, playing a strategic role in both economic and social aspects.

In Brazil, rice is one of the main crops produced, with 11.2 million tons recorded in the 2019/20 harvest (Companhia Nacional de Abastecimento [CONAB], 2020). Its production is concentrated in the southern region, which is responsible for more than $80 \%$ of the national supply; however, there has been a reduction in the cultivation area since $41,35 \%$ in the last decade (CONAB, 2020).

In recent years, the effect of global warming on rice crops has encouraged the optimization of land use to ensure high yields. Using seeds with high genetic, physical, physiological, and phytosanitary quality is an alternative to achieving these goals (Menezes, Pasqualli, Barbieri, Vidal, \& Conceição, 2012).

The use of high-quality seeds, mainly with high vigor, favors the establishment of rapid and uniform seedlings (Mathias et al., 2020; Abati, Brzezinski, Zucareli, Werner, \& Henning, 2017). 
To determine the physiological quality of seeds, laboratories need to use appropriate tests that estimate the field performance of seeds under adverse conditions (Marcos, 2015).

For rice, a minimum germination rate of $80 \%$ is required for seed commercialization, with no minimum requirement for vigor (Instrução Normativa no 45, 2013). However, not all seed lots exhibit high field emergence as this depends on their physiological response to adverse environmental conditions, which can be estimated previously through vigor tests.

High vigor seeds are capable of producing normal seedlings under suboptimal conditions for the species (International Seed Testing Association [ISTA], 2014). According to Marcos (2015), vigor testing should be used to complement the results obtained in germination tests. Vigor ensures good initial crop establishment and therefore higher yields (Tavares et al., 2013).

For many crops, such as soybean (Santorum, Nóbrega, Souza, Boller, \& Mauli, 2013), wheat (Boligon, Lúcio, Lopes, Cargnelutti, \& Garcia, 2011), and maize (Sena, Alves, \& Medeiros, 2015), the most suitable vigor tests have already been established. For rice, however, selecting the most appropriate test with high emergence correlation has reported to be a challenge.

Currently, it is difficult to select an appropriate test owing to the number of options available to analytical laboratories for testing vigor. The most widely used techniques are first count, the cold test without soil, electrical conductivity, field emergence (Barbieri, Menezes, Conceição, \& Tunes, 2011), shoot length, root length, seedling dry weight
(Lorentz \& Nunes, 2013), accelerated aging, and speed of germination (Santorum et al., 2013).

However, there is a variation between the results of laboratory vigor tests and those of field emergence. Therefore, these tests need to be evaluated to determine which is the most efficient in predicting field seedling performance. The standardization of the rice test allows the commercialization of seeds considering this seed attribute, besides allowing the estimation of the behavior of the lot in storage and in the field (Marcos, 2015).

Therefore, the hypothesis of this study was that the accelerated aging test is the most efficient in predicting the emergence of rice seedlings. Thus, this study aimed to determine which vigor tests are most efficient in predicting the emergence of rice seedlings, facilitating the selection of vigor tests for quality control analyses and pre-sowing for seed commercialization.

\section{Material and Methods}

The study was conducted in the seed testing laboratory and greenhouse of the Center for Agricultural and Veterinary Sciences (CAV) of Santa Catarina State University (UDESC), in Lages, Santa Catarina state (SC). Seeds of the 'SCS122 Miura' rice cultivar were obtained from Alto Vale do Itajaí, SC, and four and five seed lots were used in the 2016/17 and 2017/18 growing seasons, respectively.

The samples were homogenized in the laboratory and subdivided into four $350 \mathrm{~g}$ subsamples (replicates) (Ministério da Agricultura, Pecuária e Abastecimento [MAPA], 2009; Coelho, Zilio, Souza, Guidolin, \& Miquelluti, 2010) to perform the physiological 
analyses. A completely randomized design with four repetitions was used for the physiological tests.

Dormancy-breaking methods were applied in accordance with the Brazilian rules for seed testing (RAS) (MAPA, 2009). Dormancy was broken using $0.5 \%$ sodium hypochlorite solution for the germination, cold and low temperature germination tests, and by oven drying at $40{ }^{\circ} \mathrm{C}$ for $96 \mathrm{~h}$ for the accelerated aging and electrical conductivity tests. Then, the seed physiological quality was characterized using the following tests.

The germination test was performed with four repetitions of 100 seeds each. After dormancy-breaking, the seeds were sown on three sheets of germitest paper moistened with distilled water at three times the weight of the dry paper (MAPA, 2009). The sheets were then rolled up, stored in plastic bags, and placed in a Mangelsdorf germination chamber at $25 \pm 2{ }^{\circ} \mathrm{C}$ for 14 days. Counting was performed 7 and 14 days after sowing (MAPA, 2009).

Four repetitions of 100 seeds each were used for the accelerated aging test. After dormancy-breaking, the seeds were arranged on a stainless-steel grid over $40 \mathrm{~mL}$ of distilled water inside germination boxes $(11 \times 11 \times 3.5$ cm) (Krzyzanowski, Vieira, \& França, 1999), and placed in an accelerated aging chamber at 41 ${ }^{\circ} \mathrm{C}$ for 120 h (Zuchi \& Bevilaqua, 2012). Next, the same seeds were subjected to germination testing as described above.

The cold test was performed with four repetitions of 100 seeds sowed on germitest paper moistened with distilled water at three times the weight of the dry paper (MAPA, 2009; Barros, Dias, Cicero, \& Krzyzanowski, 1999). The rolled paper was placed in plastic bags at $10^{\circ} \mathrm{C}$ for 7 days (Barros et al., 1999). Next, the rolls were transferred at $25 \pm 2{ }^{\circ} \mathrm{C}$ for 7 days, followed by the final assessment (Barros et al., 1999).

In the low temperature germination, using four repetitions of 100 seeds each, the seeds were sown on germitest paper moistened with distilled water at three times the weight of the dry paper. The rolls of paper were stored in plastic bags and placed at $18^{\circ} \mathrm{C}$ for 7 days (Krzyzanowski et al., 1999). The rolls were then maintained at $25 \pm 2{ }^{\circ} \mathrm{C}$ for 7 days, followed by the final assessment.

The electrical conductivity test consisted of weighing four repetitions of 50 seeds each on an analytical balance, followed by imbibing in plastic cups containing $75 \mathrm{~mL}$ of deionized distilled water (Vieira \& Krzyzanowski, 1999). Next, the samples were placed in a chamber maintained at $25 \pm 2^{\circ} \mathrm{C}$ for $24 \mathrm{~h}$, and a conductivity meter was used to measure the electrical conductivity of the imbibing solution (Vieira \& Krzyzanowski, 1999). The results are expressed in $\mu \mathrm{S} \mathrm{cm}^{-1} \mathrm{~g}^{-1}$.

After characterization of the 'SCS122 Miura' seed lots in the laboratory, emergence tests were conducted in the field and greenhouse in each growing season. Greenhouse emergence was accomplished with all tested seed lots. However, for field emergence, only two seed lots were selected for sowing in the rice paddies located in Taió, SC.

Greenhouse emergence was evaluated in November 2017 and October 2018, with four repetitions of 50 pre-germinated seeds in trays containing $5 \mathrm{~cm}$ of water. Pre-germination was facilitated by imbibing the seeds in water for $36 \mathrm{~h}$, followed by another $36 \mathrm{~h}$ in the shade until growth stage S2 (SOSBAI, 2018). The emergence index (EI), emergence speed (ES), 
emergence percentage at 14 days, shoot and root length, and dry weight were assessed.

The El was determined by counting the number of seedlings that emerged daily; counting was performed at the same time each day. At the end of the test, the El was calculated using Maguire (1962).

The ES was also calculated based on the number of emerged seedlings observed at the same time every day, using the formula proposed by Edmond and Drapala (1958).

Shoot and root lengths were evaluated in 20 seedlings per repetition using a digital pachymeter and the results are expressed in millimeters (mm) (Nakagawa, 1999). The shoot length consisted of the measurement from the insertion point of the shoot up to the upper end of the primary leaf. The root length consisted of the measurement from the lower end of the main root until the insertion point of the shoot.

Seedling dry weight was determined using the 20 seedlings per repetition that were used previously for length measurements, without the seeds. These seedlings were weighed after drying in an oven at $50^{\circ} \mathrm{C}$ for 48 $h$, and the results are expressed in grams.

Field emergence was evaluated for two random seed lots at 14 days after sowing, in November 2017 and October 2018 in two commercial rice paddies in the municipality of Taió, SC. The assessment was performed based on the ' $X$ ' model route considering six points per area (MAPA, 2011). At each point, four launches (repetitions) were made at random using a square with dimensions of 0.5 $\mathrm{m} \times 0.5 \mathrm{~m}\left(0.25 \mathrm{~m}^{2}\right)$, and the number of emerged seedlings were counted. At the end of the evaluation of the area, the arithmetic mean of the repetitions per point was calculated, and subsequently, the number of seedlings that emerged per $\mathrm{m}^{2}$ was obtained.

The percentages were subjected to an arcsen $\sqrt{\frac{x}{100}}$ transformation, but the data are presented as untransformed values. The data were subjected to analysis of variance using the $F$ test $(p<0.05)$. When significance was verified, the means were compared using Tukey's test $(p<0.05)$. Furthermore, Pearson's correlation ( $p<0.05$ ) was used to analyze the correlation between vigor tests and greenhouse emergence, and the partial least-squares regression was used to assess the correlation between laboratory vigor test and greenhouse results with those of field emergence. All statistical analyses were performed using $R$, version 1.1.456 (R Core Team [R], 2018).

\section{Results and Discussion}

Tables 1 and 3 present the results of summary of analysis of variance all the vigor tests used to characterize the 'SCS122 Miura' seed lots during the 2016/17 and 2017/18 growing seasons.

Through the analysis of variance, a significant difference was observed between the seed lots of the 'SCS122 Miura' in the germination, electrical conductivity, cold test, low temperature germination and accelerated aging in the 2016/17 growing season (Table 1). 


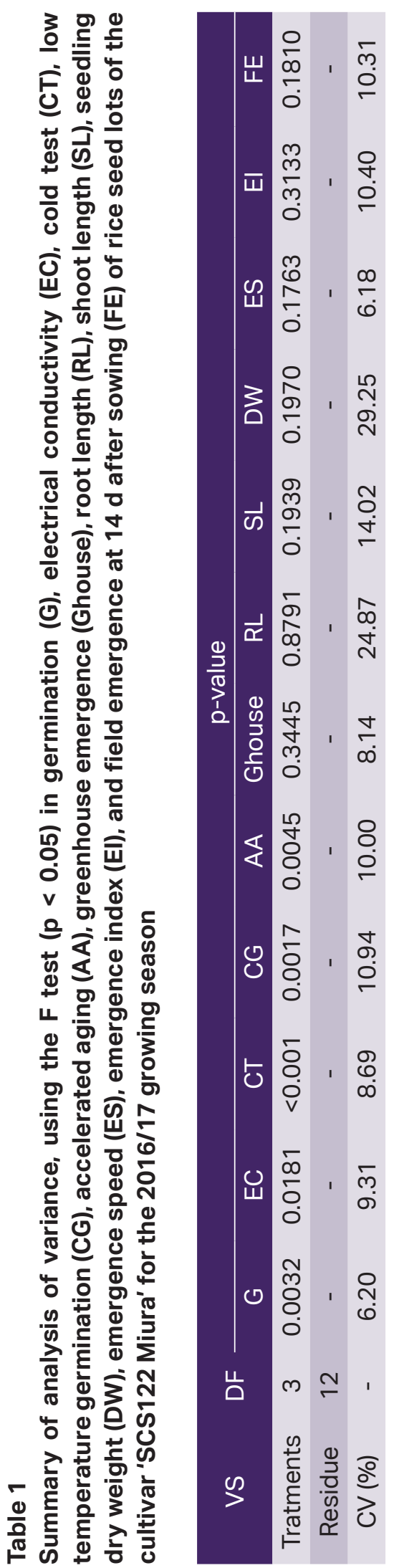

The germination rate for all lots in both growing seasons was equal to or greater than $80 \%$, consistent with the minimum required for rice seed commercialization (Brazil, 2013). This result highlights the rigor imposed on rice seed production in the state. Currently, Santa Catarina is notable nationally for producing only certified seeds (C1 and C2 categories) of rice, providing a high quality seeds to the sector.

In the laboratory analysis performed, in the 2016/17 growing season, the lots 1 and 3 were remarkable, presenting superior physiological quality in most vigor tests, whereas in the 2017/18 growing season, it was lots 4 and 5 (Tables 2 and 4). After completion of the vigor tests, these seed lots were selected for sowing in the field during the respective growing season.

Analysis of the performance of the seed lots in the laboratory tests in the 2016/17 growing season, showed that only in the accelerated aging test, did the lots 1 and 3 not differ from each other, showing a vigor of $67 \%$ and $70 \%$, respectively. However, in the remaining tests such as germination $(80 \%$ and $93 \%$, respectively), electrical conductivity (24.91 and $21.39 \mu \mathrm{S} \mathrm{cm}^{-1} \mathrm{~g}^{-1}$, respectively), cold test (37\% and $49 \%$, respectively), and low temperature germination $(49 \%$ and $64 \%$, respectively), significant differences were observed (Table 2).

In the 2017/18 growing season, through the analysis of variance, a significant difference was observed between the lots for the germination, cold test, accelerated aging and seedling dry weight between the seed lots of the 'SCS122 Miura' (Table 3). 


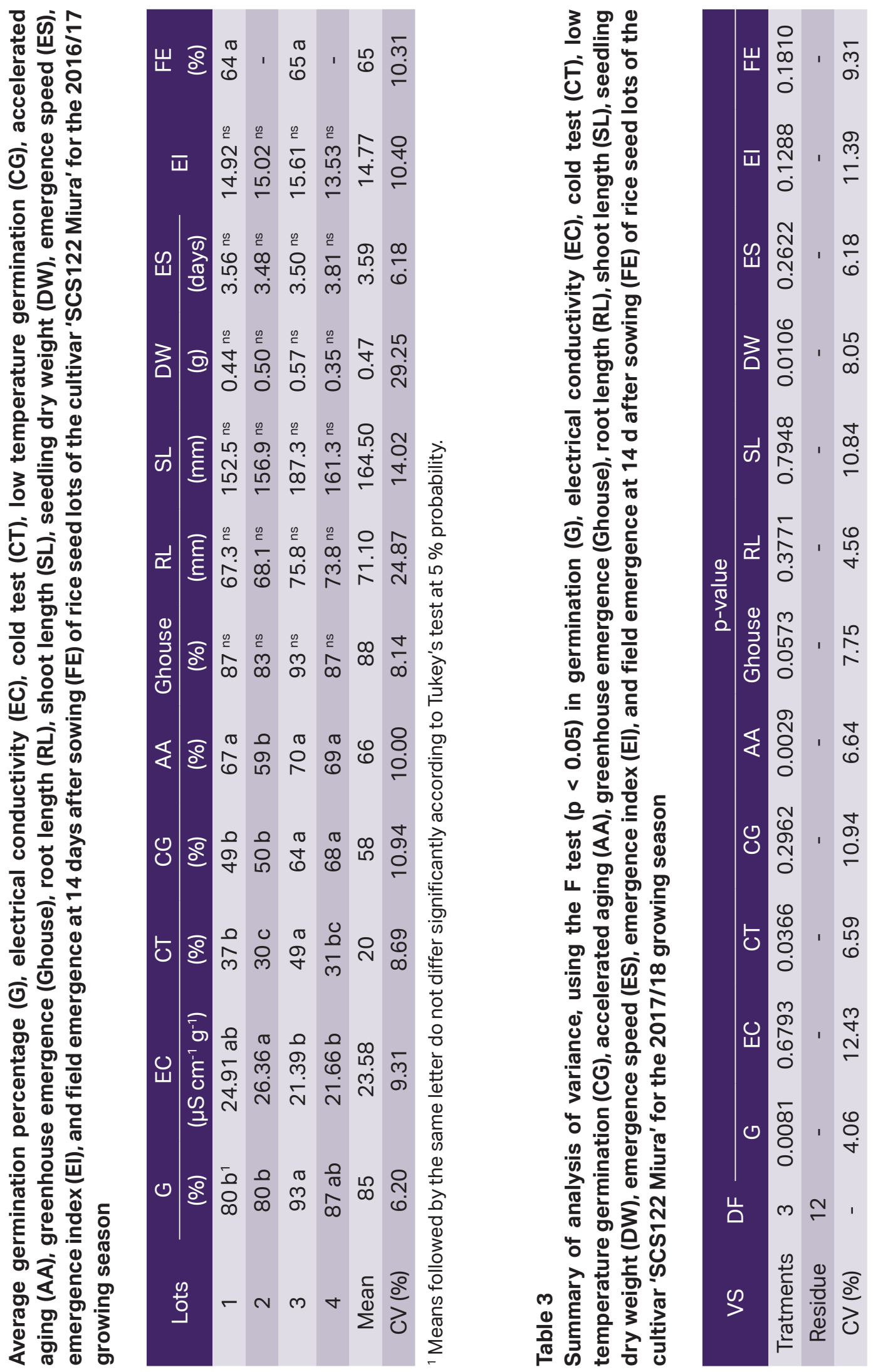


A significant difference was observed between lots 4 and 5 only in the germination test, with $88 \%$ and $80 \%$ of normal seedling germination (Table 4).

It is important to note that unlike the similar observations for field emergence, differences were observed between these same seed lots in many of the laboratory tests in both growing seasons (Table 2 and 4). This emphasizes the importance of the need to standardize a test that has high efficiency in predicting seed performance in the field.

The results of the vigor tests in the greenhouse did not differ between seed lots in the 2016/17 growing season. However, in 2017/18, lots 4 and 5 had high dry weight of seedlings, whereas lots 1 and 3 had a low dry weight of seedlings and this difference was significant. In this growing season, it is likely that the environment, mainly temperature, was the main factor influencing the seeds, interfering with the mobilization of reserves and affecting the accumulation of dry weight by the seedlings. The accelerated aging test results indicated a lower tolerance to thermal stress in lots 1 and 3 than in the other lots (Table 4). Stress caused by high temperatures is responsible for irreversible damage to seedling development (Essemine, Ammar, \& Bouzid, 2010), depending on the initial seed quality (Sbrussi \& Zucarelli, 2014).

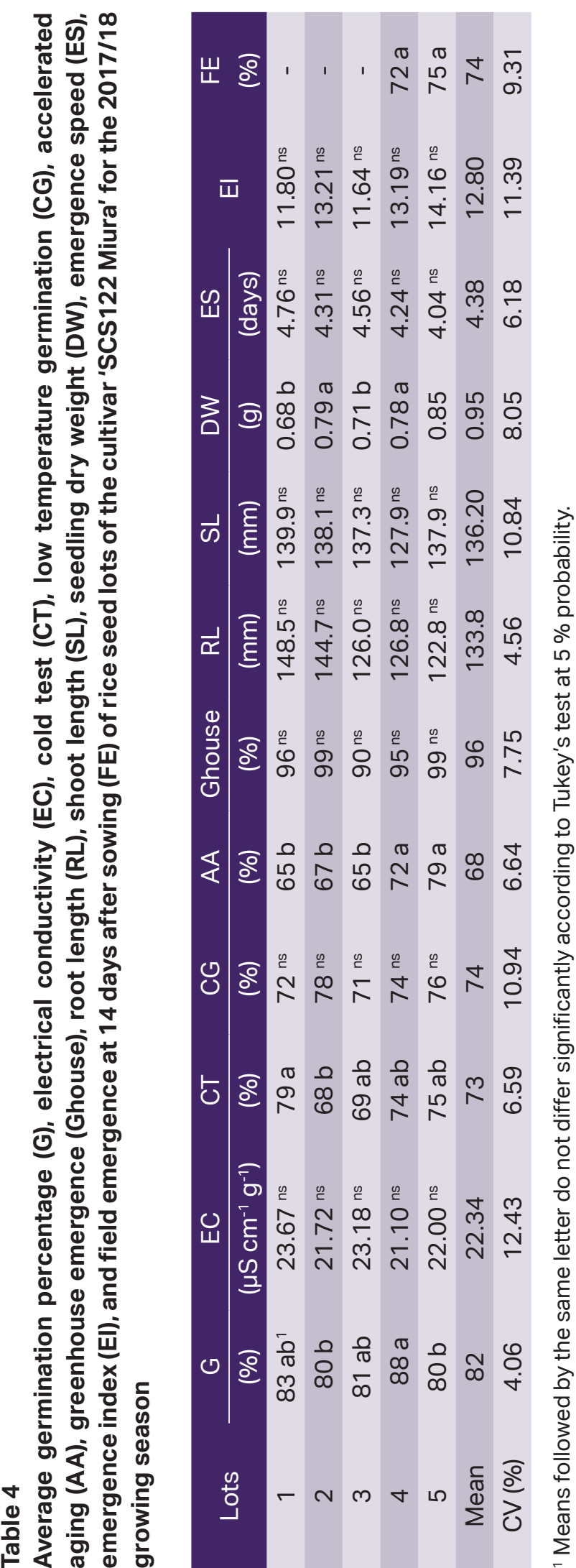


Regarding field emergence, there was no significant difference between the lots evaluated in both growing seasons. In the 2016/17 growing season, the temperature ranged from 11 to $32{ }^{\circ} \mathrm{C}$ during the field evaluation of these seed lots. In the 2017/18 growing season, the temperature ranged from 2 to $30{ }^{\circ} \mathrm{C}$. In rice cultivation, water may play a vital role in plant establishment, helping to maintain stable temperatures and contributing to early plant development. Stagnant water in irrigated rice fields has a thermoregulatory effect, increasing field temperature by up to 6 ${ }^{\circ} \mathrm{C}$ at night and 1 to $2{ }^{\circ} \mathrm{C}$ during the day (SOSBAI, 2018).

The Pearson's correlation coefficient $(r)$ is commonly used in most studies that have evaluated the relationship between results of laboratory tests and field emergence. In this study, Pearson's correlation analysis showed that in the 2017/18 growing season, the accelerated aging test, El, dry weight, and root

(a)

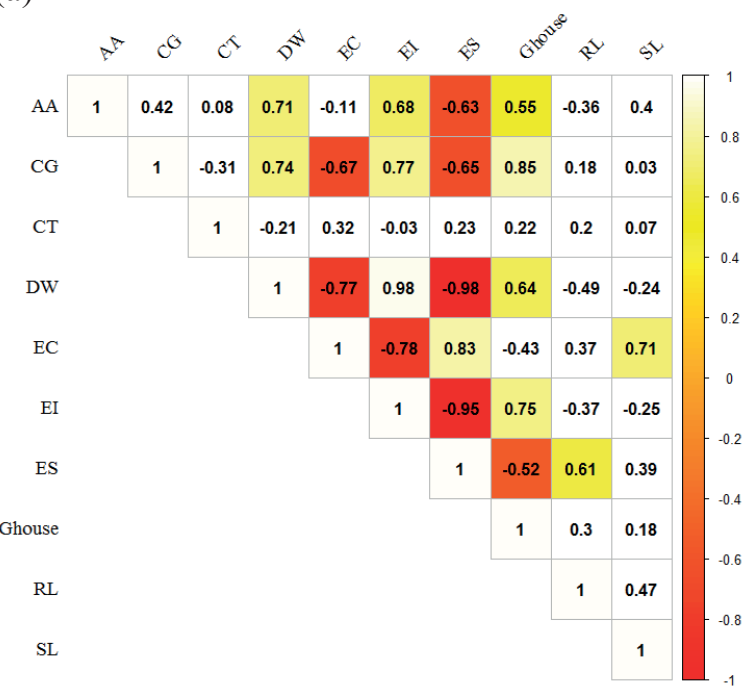

length had a positive correlation ( $>0.50$ ) with greenhouse emergence, presenting $r$ values of $0.81,0.81,0.68$, and 0.53, respectively (Figure 1 a). In the 2018/19 growing season, a positive correlation was observed with the accelerated aging test $(r=0.55)$, El $(r=0.75)$, and dry weight $(r=0.64)$ (Figure 1b).

The accelerated aging test may have been notable because the laboratory analysis conditions were similar to those found in the field during emergence (high temperature and moisture). Seed lots with high vigor deteriorate more slowly and those with low vigor have a greater decrease in viability after being exposed to similar conditions (Cardoso et al., 2019). This test has been used extensively to measure vigor in many crops such as soybean (Zuffo, Zuffo, Zmbiazzi, \& Steiner, 2017), maize (Viloria \& Natera, 2011), and wheat (Ohlson, Kryzanowski, Caieiro, \& Panobianco, 2010), because it shows a strong correlation with the storage potential and field emergence of these crops.

(b)

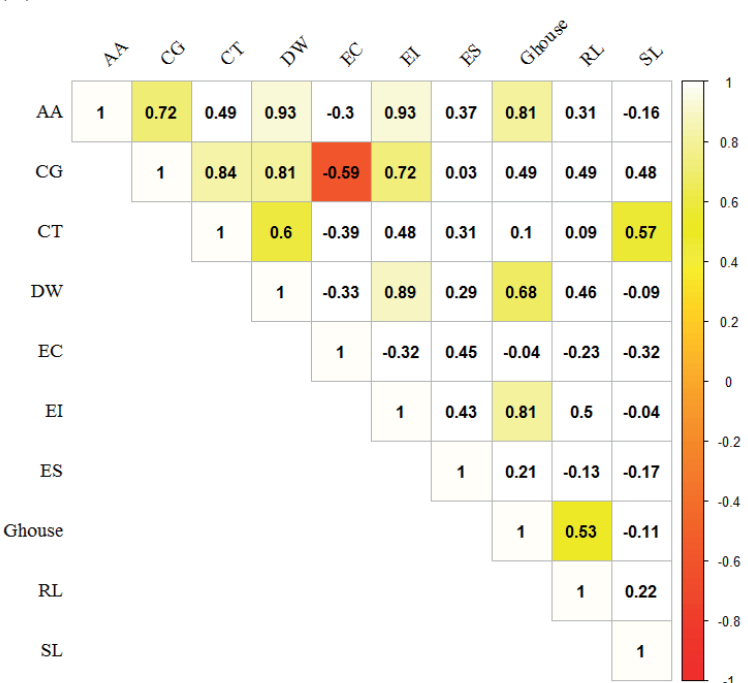

Figure 1. Pearson's correlation between vigor tests 1 and greenhouse emergence of rice seed lots of the cultivar 'SCS122 Miura' in the (a) 2017/18 and (b) 2018/19 growing seasons.

$1 \mathrm{AA}$ : Accelerated aging; CG: Low temperature germination; CT: cool germination; DW: Dry weight; EC: Electrical conductivity; El: Emergence index; ES: Emergence speed; Ghouse: Greenhouse emergence; RL: Root length; SL: Shoot length. 
In this study, the performance tests, such as the $\mathrm{El}$ and dry weight, were very sensitive in determining seed vigor, as also reported for several species by Marcos (2015). High vigor seeds show rapid emergence under unfavorable environmental conditions, with good initial seedling development and therefore greater dry weight accumulation (Mondo, Cicero, Dourado, Pupim, \& Dias, 2013). Because these seeds have a high seed reserve utilization efficiency for mobilization of resources for the development of the embryonic axis, they result in higher weight seedlings (Andrade, Coelho, \& Padilha, 2019).

The partial least-squares regression analysis verified that there was a positive correlation between greenhouse and field emergence in both growing seasons. A positive correlation was also observed in both conditions for the $\mathrm{El}$, accelerated aging, and dry

(a)

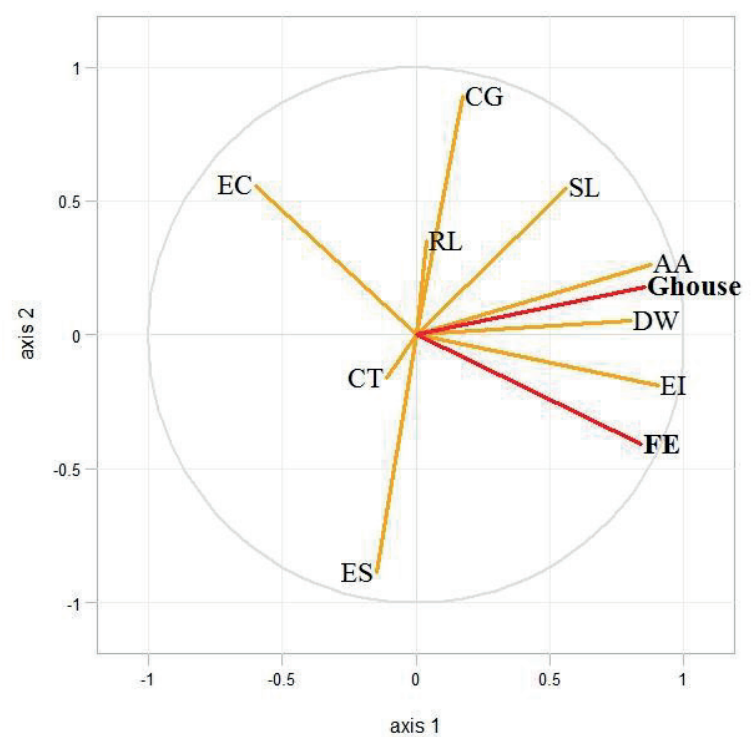

weight (Figure 2). Therefore, rice seeds with the highest El and vigor as denoted by accelerated aging and dry weight accumulation exhibited the highest emergence percentages in the field and greenhouse conditions.

Electrical conductivity showed a negative correlation with greenhouse and field emergence in both growing seasons (Figure 2). This test is based on measuring the leachates related to membrane integrity that are released by the seeds into the solution during soaking, the amount of leachate in the solution being related to the amount of damage to the membrane (Kavan, Catão, Caixeta, Rocha, \& Castilho, 2019). Under field conditions, leakage of exudates after sowing can stimulate the growth of pathogens and impair seedling emergence (Marcos, 2015). Therefore, rice seeds that showed high levels of leachates had a low emergence percentage.

(b)

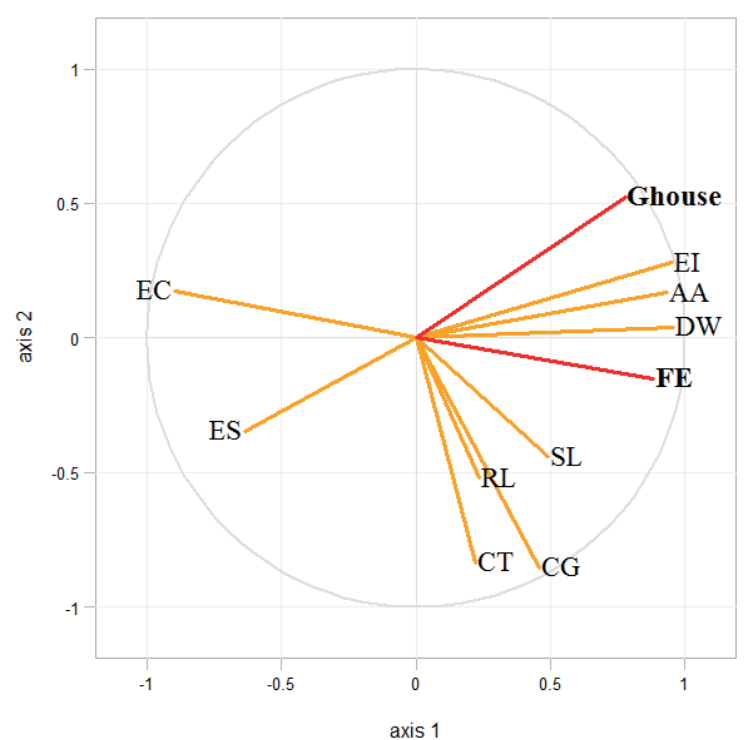

Figure 2. Partial least-squares regression analysis of the physiological laboratory tests and greenhouse and field emergence ${ }^{2}$ of rice seed lots of the cultivar 'SCS122 Miura' in the (a) 2017/18 and (b) 2018/19 growing seasons.

2 Ghouse: Greenhouse emergence; FE: Field emergence; CG: Low temperature germination; EC: Electrical conductivity; AA: Accelerated aging; El: Emergence index; DW: Dry weight; SL: Shoot length; RL: Root length, CT: cool germination; ES: Emergence speed. 
ES was negatively correlated with greenhouse and field emergence (Figure 2). A similar behavior was observed by Marcos (2013), who reported that less vigorous seed lots displayed longer germination times.

The results of this study demonstrated that vigor tests such as the accelerated aging, $\mathrm{El}$, and dry weight accumulation have a high correlation with seedling emergence. Similarly, Khan et al. (2010) concluded that in wheat, the accelerated aging test and germination index predict seed performance in field emergence.

It is important to consider that a single test cannot detect all possible seed performance characteristics, as vigor does not refer to a unique characteristic (Marcos, 2015). However, considering the practicality of performing each vigor test and optimization of time to obtain results to help technicians, the accelerated aging test is the best option among laboratory tests for quality control and pre-sowing analysis.

In addition, further work with more cultivars and sowing conditions are needed to contribute to these findings.

\section{Conclusion}

Accelerated aging ( $41^{\circ} \mathrm{C}$ for $120 \mathrm{~h}$ ) is one of the most efficient tests for predicting the emergence of rice seedlings and the best option for laboratory analysis of quality control and pre-sowing owing to its practicality and time required for execution.

\section{Acknowledgment}

To financial support of CAPES and TR653PAP/UDESC/FAPESC. The Cooperativa
Regional Agropecuária Vale do Itajaí for donating the seeds. The corresponding author (Coelho, C.M.M.) thanks Conselho Nacional de Desenvolvimento Científico e Tecnológico (CNPq) for productivity scholarship. This article is part of Garcia, J., Masters dissertation.

\section{References}

Abati, J., Brzezinski, C., Zucareli, C., Werner, F., \& Henning, F. (2017). Seed vigor and amount of soybean straw on seedling emergence and productive performance of wheat. Semina: Ciências Agrárias, 38(4), 21792186. doi: 10.5433/1679-0359.2017v38n $4 \mathrm{p} 2179$

Andrade, G. C. de, Coelho, C. M. M., \& Padilha, M. S. (2019). Seed reserves reduction rate and reserves mobilization to the seedling explain the vigour of maize seeds. Journal of Seed Science, 41(4), 488-497. doi: 10. 1590/2317-1545v41n4227354

Barbieri, A. P. P., Menezes, N. L. de, Conceição, G. M., \& Tunes, L. M. de. (2011). Teste de lixiviação de potássio para a avaliação do vigor de sementes de arroz. Journal of Seed Science, 33(4), 616-625. doi: 10. 1590/S0101-31222012000100015

Barros, A. S. R., Dias, M. C. L. L., Cícero, S. M., \& Krzyzanowski, F. C. (1999). Teste de frio. In F. C. Krzyzanowski, R. D. Vieira, \& J. B. França Neto (Eds.), Vigor de sementes: conceitos e testes (pp. 1-13). Londrina: ABRATES.

Boligon, A. A., Lúcio, A. D., Lopes, S. J., Cargnelutti, A. C., Fo., \& Garcia, D. C. (2011). Wheat seedling emergence estimated from seed analysis. Scientia Agricola, 68(3), 336-341. doi: 10.1590/S0103-9016 2011000300010 
Cardoso, F. B., Rego, C. H. Q., Oliveira, I. C. de, Zuffo, A. M., Cândido, A. C. da, \& Alves, C. Z. (2019). Vigor testings for evaluating the physiological quality of chia seeds. Semina: Ciências Agrárias, 40(6), 2891-2904. doi: 5433/1679-0359.2019v40n6Supl2p2891

Coelho, C. M. M., Zilio, M., Souza, C. A., Guidolin, A. F., \& Miquelluti, D. J. (2010). Características morfo-agronômicas de cultivares crioulas de feijão comum em dois anos de cultivo. Semina: Ciências Agrárias, 31(1), 11771186. doi: 10.5433/1679-0359.2010v31 n4Sup1p1177

Companhia Nacional de Abastecimento (2020). Acompanhamento da safra brasileira de grãos (v. 7-safra 2019/20 Décimo segundo levantamento). Brasília: CONAB.

Edmond, J. B., \& Drapala, W. I. (1958). The effects of temperature, sand and soil, and acetone on germination of okra seeds. Journal of the American Society for Horticultural Science, 71(2), 428-434.

Essemine, J., Ammar, S., \& Bouzid, S. (2010). Impact of heat stress on germination and growth in higher plants: physiological, biochemical and molecular repercussions and mechanisms of defense. Journal of Biological Sciences, 10(6), 565-572. doi: 10.3923/jbs.2010.565.572

Instrução Normativa $n^{\circ} 45$, de 17 de setembro de 2013. Dispõe sobre padrões de produção e a comercialização de sementes de grandes culturas. Recuperado de http://www.agricultura. gov.br/assuntos/insumos-agropecuarios/ insumos-agricolas/sementes-e-mudas/ publicacoes-sementes-e-mudas/copy _of_INN45de17desetembrode2013.pdf
International Seed Testing Association (2014). Seed vigour testing. International Rules for Seed Testing. Zurich: Switzerland.

Kavan, H. C., Catão, H. C. R. M., Caixeta, F., Rocha, C. da S., \& Castilho, I. M. (2019). Accelerated aging periods and its effects on electric conductivity of popcorn seeds. Revista de Ciências Agrárias, 42(1), 40-48. doi: 10.19084/RCA.15237

Khan, A. Z., Shah, P., Mohd, F., Khan, H., Amanullah, S., Perveen, S., Zubair, M. (2010). Vigor tests used to rank seed lot quality and predict field emergence in wheat. Pakistan Journal of Botany, 42(5), 31473155. doi: 10.3923/ajpp.2007.311.317

Krzyzanowski, F. C., Vieira, R. D., \& França, J. de B., Neto. (1999). Vigor de sementes: conceitos e testes. Londrina: Abrates.

Lorentz, L. H., \& Nunes, U. R. (2013). Relações entre medidas de qualidade de lotes de sementes de arroz. Revista Ciência Agronômica, 44(4), 798-804. doi: 10.1590/ S1806-66902013000400017

Maguire, J. D. (1962). Speed of germination: aid in selection and evaluating for seedling emergence and vigor. Crop Science, 2(1), 176-177. doi: 10.2135/cropsci1962.0011 $183 \times 000200020033 x$

Marcos, J., Fo. (2013). Importância do potencial fisiológico da soja. Informativo Abrates, 23(1), 21-24.

Marcos, J., Fo. (2015). Seed vigor testing: an overview of the past, present and future perspective. Scientia Agricola, 72(4), 363374. doi: 10.1590/0103-9016-2015-0007

Mathias, V., Coelho, C. M. M., Araldi, C. G., Nerling, D., Borba, P. T. D. de, \& Uarrota, V. G. (2020). Characterization of the physiological quality of soybean seeds 
produced in Santa Catarina State. Semina: Ciências Agrárias, 41(1), 49-60. doi: 10. 5433/1679-0359.2020v41n1p49

Menezes, N. L. de, Pasqualli, L. L., Barbieri, A. P. P., Vidal, M. D., \& Conceição, G. M. (2012). Temperaturas de secagem na integridade física, qualidade fisiológica e composição química de sementes de arroz. Pesquisa Agropecuária Tropical, 42(4), 430-436. doi: 10.1590/S1983-40632012000400011

Ministério da Agricultura, Pecuária e Abastecimento. (2009). Regras para análise de sementes. Brasília: MAPA/ ACS. Recuperado de http://www.agricultura. gov.br/assuntos/laboratorios/arquivospublicacoes-laboratorio/regras-paraanalise-de-sementes.pdf/view

Ministério da Agricultura, Pecuária e Abastecimento. (2011). Guia de inspeção de campos para produção de sementes. Ministério da Agricultura, Pecuária e Abastecimento. Secretaria de Defesa Agropecuária (ed. rev. e atual.). Brasília: MAPA/ ACS 3.

Mondo, V. H. V., Cicero, S. M., Dourado, D., Neto, Pupim, T. L., \& Dias, M. A. N. (2013). Response of maize and soybean to variability in stand uniformity. Agronomy Journal, 97(4), 1263-1269. doi: 10.2134/ agronj2005.0006

Nakagawa, J. (1999). Testes de vigor baseados no desempenho das plântulas. In F. C. Krzyzanowski, R. D. Vieira, J. B. FrançaNeto (Eds.), Vigor de sementes: conceitos e testes (cap. 2, pp. 1-24). Londrina, PR: Abrates.

Ohlson, O. C., Krzyzanowski, F. C., Caieiro, J. T., \& Panobianco, M. (2010). Teste de envelhecimento acelerado em sementes de trigo. Journal of Seed Science, 32(4), 118-124. doi: 10.1590/S0101-312220100 00400013

R Core Team (2018). R: A language and environment for statistical computing. Austria: $\mathrm{R}$ Foundation for Statistical Computing. Retrieved from https://www.Rproject.org/

Santorum, M., Nóbrega, L. H. P., Souza, E. G. de, Santos, D. dos, Boller, W., \& Mauli, M. M. (2013). Comparison of tests for the analysis of vigor and viability in soybean seeds and their relationship to field emergence. Acta Scientiarum Agronomy, 35(1), 83-92. doi: 10.4025/actasciagron. v35i1.14955

Sbrussi, C. A. G., \& Zucareli, C. (2014). Germinação de sementes de milho com diferentes níveis de vigor em resposta à diferentes temperaturas. Semina: Ciências Agrárias, 35(1), 215-226. doi: 10. 1590/0103-8478cr20130906

Sena, D. V. dos A., Alves, E. U., \& Medeiros, D. S. de. (2015). Vigor de sementes de milho cv. 'Sertanejo' por testes baseados no desempenho de plântulas. Ciência Rural, 45(11), 1910-1916. doi: 10.1590/0103-84 $78 c r 20120751$

Sociedade Sul-Brasileira de Arroz Irrigado (2018). Arroz irrigado: recomendações técnicas da pesquisa para o Sul do Brasil. Gramado: SOSBAI.

Tavares, L. C., Rufino, C. de A., Brunes, A. P., Tunes, L. M. de, Barros, A. C. S. A., \& Peske, S. T. (2013). Desempenho de sementes de soja sob deficiência hídrica: rendimento e qualidade fisiológica da geração F1. Ciência Rural, 43(8), 1357-1363. doi: 10. 1590/S0103-84782013000800003 
Vieira, R. D., \& Krzyzanowski, F. C. (1999). Teste de condutividade elétrica. In F. C. Krzyzanowski, R. D. Vieira, \& J. B. França Neto (Eds.), Vigor de sementes: conceitos e testes (pp. 1-26). Londrina: ABRATES.

Viloria, H., \& Natera, J. R. M. (2011). Relación entre la conductividad eléctrica, $\mathrm{pH}$ del agua de remojo, germinación de semillas y crecimiento de plántulas de maíz (Zea mayz L.) bajo dos condiciones experimentales. Scientia Agropecuaria, 2(4), 213-228. doi: 10.1590/0103-8478cr20120751
Zuchi, J., \& Bevilaqua, G. A. P. (2012). Qualidade fisiológica de sementes de arroz armazenadas em diferentes embalagens e temperaturas. Pelotas: (Boletim de Pesquisa, 163). EMBRAPA Clima Temperado.

Zuffo, A. M., Zuffo, J. M., Jr., Zambiazzi, E. V., \& Steiner, F. (2017). Physiological and sanitary quality of soybean seeds harvested at different periods and submitted to storage. Pesquisa Agropecuária Tropical, 47(3), 312-320. doi: 10.1590/1983-40632016v4747576 